\title{
PENATALAKSANAAN DAN FOLLOW UP BERKALA PADA AMETROPIA AMBLIOPIA
}

\author{
Laya M. Rares
}

\author{
Bagian Ilmu Kesehatan Mata Fakultas Kedokteran Universitas Sam Ratulangi Manado \\ Email: layarares@yahoo.com
}

\begin{abstract}
Amblyopia is a decline of visual acuity, unilateral or bilateral, even after a maximal correction and is not directly related to any structural disorders of the eye or posterior visual pathway. We reported the case of an 8-year-old boy with bilateral amblyopia treated with a full correction eye glass therapy. The patient underwent a general eye examination, a set of tests related to the causes of amblyopia, and an eye glass correction to obtain BCVA in both eyes. The results showed VOD 5/60 S-2.50 = C-2.50 x $180^{\circ} 6 / 18$, VOS 4/60 S-2.00 = C-2.75 $\mathrm{X} 180^{\circ} 6 / 15$, and normal intraoccular pressures of both eyes by palpation. Light reflex of ODS was normal with no RAPD. The eyeball positions were normal without any anomaly. The eyeball movements were good in all directions, while the Ishihara color blindness test showed a normal result. The spacious view was normal, and the visible image of funduscopy had no anomaly. The patient was treated wih a correction of anomaly refraction by using eyeglasses as the initial treatment. In the case that there is no significant improvement in the initial therapy, a patching therapy and a periodical follow-up in the process of the eyesight rehabilitation is suggested. Conclusion: Based on all the tests performed, the diagnosis of this patient was bilateral amblyopia. It was expected that by the resumption of wearing eyeglasses for the anomaly refraction correction and eyesight rehabilitation, and with periodical followups the patient's condition would improve.
\end{abstract}

Keywords: bilateral amblyopia, anomaly refraction, full correction therapy.

\begin{abstract}
Abstrak: Ambliopia adalah penurunan ketajaman penglihatan unilateral atau bilateral walaupun telah diberikan koreksi terbaik, yang tidak berhubungan langsung dengan kelainan struktural mata ataupun jaras penglihatan posterior. Kami melaporkan kasus seorang anak laki-laki berusia 8 tahun dengan ambliopia bilateral yang telah diberikan terapi kacamata full correction. Pada kasus ini telah dilakukan pemeriksaan mata menyeluruh, serangkaian tes yang berkaitan dengan penyebab ambliopia, dan koreksi kaca mata untuk mencapai BCVA (Best Corection Visual Aquity) pada kedua mata. Hasil pemeriksaan memperihatkan VOD 5/60 S-2.50 C-2.50 x180 6/12, VOS 4/60 S-2.00 C -2.75x180 6/15, tekanan intraokuler (dengan palpasi) mata kanan dan kiri normal, RAPD (-), ortoforia, tes warna normal, serta lapang pandang normal dan segmen posterior dalam batas normal. Koreksi kelainan refraksi dengan kacamata sebagai penanganan awal dan direncanakan untuk terapi patching bila tidak terdapat kemajuan yang bermakna dari terapi awal, serta follow up berkala dalam proses rehabilitasi penglihatan. Simpulan: Berdasarkan hasil pemeriksaan yang telah dilakukan, diagnosis pada kasus ini ambliopia bilateral. Setelah terapi koreksi kelainan refraksi menggunakan kaca mata dan rehabilitasi penglihatan dengan follow up berkala diharapkan visus optimal dapat tercapai.
\end{abstract}

Kata kunci: ambliopia bilateral, refraksi anomali, terapi full correction. 
Ambliopia berasal dari bahasa Yunani, amblyos, yang berarti tumpul atau pudar, dan opia yang berarti mata. ${ }^{1,2}$ Ambliopia adalah penurunan ketajaman penglihatan, walaupun sudah mendapatkan koreksi terbaik, dapat bersifat unilateral ataupun bilateral, yang tidak dapat dihubungkan langsung dengan kelainan struktural mata ataupun jaras penglihatan posterior. ${ }^{1-3} \mathrm{Am}-$ bliopia disebut juga sebagai abnormalitas perkembangan visual akibat abnormalitas stimulasi visual.

Patofisiologi ambliopia memperlihatkan adanya kerusakan penglihatan sentral, sedangkan penglihatan perifer normal. Periode kritis sesuai dengan perkembangan sistem penglihatan yang kurang mendapatkan stimulasi, antara lain akibat strabismus atau kelainan refraksi yang bermakna. Untuk penglihatan yang baik dibutuhkan media refraksi yang harus jernih dan bayangan terfokus sama pada kedua mata. Bila bayangan kabur pada satu mata, atau bayangan tidak sama pada kedua mata, maka jaras penglihatan tidak dapat berkembang dengan baik, bahkan memburuk. Pada keadaan demikian, otak akan 'mematikan' mata yang tidak fokus dan akan bergantung penglihatannya pada mata dominan untuk melihat. Stimulasi penglihatan merupakan hal yang sangat berpengaruh terhadap perkembangan penglihatan. Penglihatan binokular normal terjadi sejak saat lahir, yaitu mulai dari masa bayi dan menjadi lengkap pada usia 8-10 tahun. ${ }^{4-6}$

Ambliopia diklasifikasikan atas beberapa bagian sesuai dengan gangguan/ kelainan yang menjadi penyebabnya, yaitu: ambliopia strabismik, anisometropia, ametropia, dan deprivisasi.

Umumnya, ambliopia dapat ditangani secara efektif dalam satu dekade pertama. Makin cepat dilakukan tindakan penanganan, maka semakin besar peluang keberhasilan. ${ }^{1}$

\section{LAPORAN KASUS}

Seorang anak berusia 8 tahun, suku Minahasa, berobat ke Poliklinik Mata RSU Prof. Dr. R.D. Kandou Manado dengan keluhan utama penglihatan kabur pada kedua mata. Keluhan ini mulai dirasakan sejak 2 tahun lalu. Pasien sudah memeriksakan matanya sekitar satu tahun sebelumnya dan telah diberikan resep kacamata, tetapi setelah 6 bulan pemakaian kacamatanya pecah dan pasien sudah tidak menggunakan kacamata lagi dan tidak pernah memeriksakan penglihatannya lagi. Pasien datang ke Poliklinik Mata karena merasakan penglihatannya sudah lebih kabur.

Dari hasil anamnesis tidak didapatkan anggota keluarga yang menderita kelainan yang sama. Riwayat kehamilan dan persalinan normal, dan perkembangan fisik baik. Pemeriksaan fisik umum dari pasien baik, semuanya berada dalam batas normal.

Pada pemeriksaan oftalmologik didapatkan hasil VOD 5/60 dan VOS 4/60, serta TIODS normal per palpasi. Refleks cahaya ODS normal, RAPD (-), tes warna dan lapangan pandang normal, serta segmen anterior dan posterior dalam batas normal.

Pada pemeriksaan Hirschberg, refleks kornea tepat di sentral pada kedua mata, worth's four dot test normal, dan Amsler grid (kisi-kisi Amsler) normal. Pada pemeriksaan refraksi secara objektif dengan menggunakan autorefraktometer (setelah $m$. sphincter pupillae dilumpuhkan dengan siklopentolat $1 \%$ ) didapatkan hasil VOD $-2.75 \sim \mathrm{C}-2.50 \mathrm{x} 7^{0}$ dan VOS $-2.25 \sim \mathrm{C}-2.75 \mathrm{x}$ $178^{0}$. Setelah dikonfirmasi dengan pemeriksaan streak retinoscopy pada jarak kerja $67 \mathrm{~cm}$ didapatkan hasil koreksi: OD S-2.50 C-2.00 x $180^{\circ} \quad 6 / 15$ dan OS S-3.50 C-2.50 × $180^{0}$ 6/18. Berdasarkan hasil yang diperoleh, dilakukan evaluasi visus secara subyektif dan didapatkan hasil: OD S-2.00 C-2.00 x $180^{\circ} 6 / 5$ dan OS S-2.50 C-2.50 x $180^{\circ} 6 / 18$, kemudian diberikan resep kaca mata.

Pasien disarankan kembali follow up setelah penggunaan kacamata koreksi selama 4 minggu untuk mengevaluasi perbaikan penglihatan dan rencana koreksi ukuran kacamata bila dengan ukuran yang baru penglihatan menjadi lebih baik. Sangat diharapkan kerjasama dari orang tua dalam masa evaluasi dan perbaikan 
penglihatan mata pasien.

\section{BAHASAN}

Berdasarkan anamnesis, kekaburan pada kedua mata pasien ini sudah sejak lama dan baru disadari setelah pasien mulai sekolah. Setelah mendapatkan koreksi kaca mata setahun lalu pasien hanya menggunakannya selama 6 bulan dan tidak melakukan follow up lanjutan; hal ini menyebabkan hasil yang diperoleh tidak optimal dan beratnya ambliopia terus bertambah.

Beberapa pemeriksaan telah dilakukan untuk mengetahui penyebab ambliopia pada kasus ini. Sebagai penyebabnya ialah gangguan refraksi yang cukup berat. Hal ini sesuai dengan acuan pustaka bahwa penyebab ambliopia yang tersering ialah kelainan refraksi, baik yang anisometropia maupun isometropia. ${ }^{1-3}$

Penentuan ketajaman penglihatan mata merupakan hal yang sangat penting karena berdasarkan hasil pemeriksaan dapat ditentukan berat ringannya ambliopia serta perbaikan yang diperoleh dari hasil terapi yang diberikan. Pemeriksaan ini membutuhkan keahlian dan kesabaran dari pemeriksa dan sikap kooperatif dari pasien, karena dalam mengevaluasi mata pada anak tentunya jauh berbeda dibandingkan dengan pada pasien dewasa. ${ }^{6-7}$

Pemeriksaan Hirschberg dilakukan untuk melihat ada tidaknya deviasi dari bola mata. Pada pasien ini refleks kornea tepat pada sentral; hal ini membuktikan bahwa tidak ada kesan strabismus pada mata yang dapat menyebabkan ambliopia. Pada cover-uncover test yang dilakukan juga tidak memperlihatkan adanya suatu phoria ataupun tropia. Pada segmen anterior dan posterior tidak didapatkan kelainan. Hal ini dilakukan untuk mengetahui secara pasti penyebab dari ambliopia pada kasus ini. Penyebab ambliopia cukup beragam yang diakibatkan adanya kekaburan atau ketidak jernihan dari media refraksi yang dapat menghalangi persepsi objek yang dilihat. Hal ini tentunya membutuhkan pemeriksaan yang cermat. ${ }^{7,8}$

Worth's four dot test dilakukan untuk menentukan adanya supresi pada salah satu mata. Pada pemeriksaan ini digunakan 4 warna cahaya yaitu 2 berwarna hijau, 1 warna merah, dan 1 warna kuning (gabungan antara merah dan hijau), untuk mengetahui apakah pasien berespon normal dan tidak mengalami supresi pada salah satu mata; hal ini terjadi akibat visus dari kedua mata sama-sama menurun. Pemeriksaan Amsler grid dan Ishihara menunjukkan fungsi makula retina normal. ${ }^{7,8}$

Serangkaian pemeriksaan telah dilakukan untuk mengetahui penyebab utama ambliopia pada pasien ini. Sebagai hasil akhir ialah ambliopia refraktif isometropia oleh karena didapatkan kelainan refraksi pada kedua mata sama. Penyebab ambliopia refraktif adalah hiperopia yang melebihi 5D, miopia lebih dari 10D, dan astigmatisma yang melebihi 2D. ${ }^{1,3,6}$

Penanganan yang diberikan terhadap pasien ini ialah terlebih dahulu menyingkirkan penyebab organik, dan selanjutnya diberikan kacamata full correction agar bayangan retina menjadi jelas. ${ }^{7,8}$ Pada pasien ini dilakukan cycloplegic refraction menggunakan siklopentolat $1 \%$. Berdasarkan acuan pustaka, pasien dengan ametropia bilateral dapat diterapi dengan kaca mata full correction, dan sebagian besar anak-anak berusia 3-10 tahun memperoleh penglihatan $6 / 7,5$ atau lebih dalam setahun. Pada pasien ini juga direncanakan untuk dilakukan patching dengan aktivitas menggunakan penglihatan selama 2 jam setiap hari untuk merangsang penglihatannya.

Follow up berkala perlu dilakukan pada pasien ini untuk mendapatkan penglihatan optimal yang lebih cepat serta mempertahankan penglihatan yang telah dicapai. Amblyopia Treatment Studies menyatakan bahwa $25 \%$ pasien ambliopia mengalami kekambuhan, dan risiko tejadi lebih besar pada mereka yang menghentikan terapi secara tiba-tiba. Pada pasien ini, setelah menggunakan kacamata koreksi selama 1 tahun secara tiba-tiba tidak menggunakannya lagi dengan alasan kaca mata pecah. Selain itu, orang tua pasien tidak melakukan upaya follow up untuk 
mendapatkan koreksi kacamata lagi, sehingga terjadi penurunan penglihatan yang lebih dari keadaan sebelumnya. Faktor kegagalan penanganan ambliopia tergantung pada jenis ambliopia, usia saat mulai diterapi, serta derajat beratnya ambliopia.

\section{SIMPULAN}

Berdasarkan hasil pemeriksaan yang telah dilakukan, pada kasus ini ditegakkan diagnosis ambliopia bilateral oleh karena didapatkan kelainan refraksi yang sama pada kedua mata sama (refraktif isometropia). Hal ini diakibatkan ketidak patuhannya dalam follow up yang berkala setelah diterapi satu tahun yang lalu.

\section{DAFTAR PUSTAKA}

1. American Academy of Ophthalmology Pediatric Ophthalmology/Strabismus Panel. Preferred Practice Pattern ${ }^{\circledR}$ Guidelines. Amblyopia [monograph online]. San Francisco, CA: American Academy of Ophthalmology; 2012. Available at: www.aao.org/ppp.

2. Wright KW. Strabismus and amblyopia. In: Wright KW and Spiegel PH, editors. A Textbook of Pediatric Ophthalmology and Strabismus (Second Edition). USA, New York: Springer Verlag, 2003; p.125-292.

3. Repka M. Amblyopia management. In:
Hoyt CS, Taylor D. Pediatric Ophthalmology and Strabismus (Fourth Edition) [monograph online]. China: Saunders Elsevier, 2013; p.726-732.

4. Basmak H, Yildirim N, Topbas S, Ozer A, Erol N, Gursoy H. Pediatric Ophthalmology/Eye and Disorders [monograph online]. Croatia, Shanghai: Intech Publication. 2003; p. 56-80. Available from: http://cdn.intechopen. com/pdfs/30824/InTech-Pediatric_oph thalmology_eye_and_disorders.pdf.

5. The Pediatric Eye Disease Investigator Group. A randomized trial of atropine vs. patching for treatment of moderate amblyopia in children. Arch Ophthalmol. 2002;120(3):268-78.

6. Clarke M. Modern treatment of amblyopia. In: Lorentz B, Moore AT, Pediatric Ophthalmology, Neurology, Genetics. Berlin: Springer, 2006; p.37-49.

7. Cotter SA, Edward AR, Wallace DK, Beck RW, Arnold RW, Astle WF. Treatment of anisometropic amblyopia in children with refractive correction. Ophthalmology. 2006;113(6):895-903.

8. Wallace DK, Chandler DL. Treatment of bilateral refractive amblyopia in children three to less than 10 years of age. Am J Ophtalmology. 2007; 114(4):487-96.

9. Nelson LB, Olitsky SE. Pediatric eye examination. In: Harley's Pediatric Ophthalmology. Philadelphia: Lippincot Williams \&Wilkins, 2005; p.84-93. 